\title{
Psychological Predicament of Freshmen in the Course of Computer Programming and Its Countermeasures
}

\author{
Jianwei Zhang \\ School of Computer Science and Engineering \\ South China University of Technology \\ Guangzhou, China
}

\begin{abstract}
Freshmen major in computer and engineering have to learn high level language programming. According to years of teaching experience, students have psychological predicaments in this process, leading to difficulties in learning. Practical application proves it has good effects to give countermeasures to the problems. Students overcome learning and psychological difficulties within a few weeks, become interested in learning this course, and the learning effects improve.
\end{abstract}

Keywords—psychological predicament; freshmen; countermeasures

\section{INTRODUCTION}

The great differences in learning styles of colleges and high schools make freshmen feel inadaptable to the teaching in colleges, so psychological problems related to learning happen frequently, learning efficiency reduces and students feel blue. If teachers fail to guide timely, students will lose confidence and give themselves up as hopeless, which will greatly influence the whole college life. Therefore, it is of vital importance for freshmen to adapt to learning styles in colleges as soon as possible.

The programming course is distinctly important in engineering major. In the information era, it is the most basic requirement of engineering students to grasp a computer language. $\mathrm{C}++$ language is the one of the most widely-used languages at present. The course of $\mathrm{C}++$ Programming is provided in computer major and other engineering majors at home. The teaching of this course directly influences engineering students' computer literacy and application ability and the teaching quality of courses requiring computer programming. Research results related to teaching reform of $\mathrm{C}++$ Programming emerge in large numbers in recent years. [1-5] According to the freshmen's adaptation to college learning and the course of $\mathrm{C}++$ Programming, countermeasures for their learning are discussed in detail, in order to enhance confidence and interests of students in learning this course and improve teaching effects.

\section{PSYCHOLOGICAL PREDICAMENTS OF FRESHMEN IN THE COURSE OF C++ PROGRAMMING}

\section{A. Differences of Learning between Colleges and High Schools}

The differences of learning between colleges and high schools are as follows:

- The course contents in high school are limited. Except for Chinese and English, some depend on accumulation after school and others are confined to contents in textbooks; college courses establish professional knowledge system and require students to learn basic knowledge and skills of this course. The course contents are not confined to textbook but require students to expand contents independently under the guidance of teachers and search for information to solve problems independently. It is difficult for freshmen to adapt and their consciousness of independent learning is not established.

- In high schools, students grasp textbook contents and pursue accuracy and efficiency in solving problems through a large number of repeated exercises, in order to get high marks in finite time of college entrance examination. In colleges, the class hours are compact and have fast progress. Students have to learn several courses in each semester and have no time to exercise repeatedly. Therefore, freshmen fail to timely digest course contents and have difficulty in learning subsequent contents.

- In high schools, students depend on teachers to a large extent and first seek help from teachers when facing learning problems. In colleges, different from high school teachers who provide 24-hour service for students, except for teaching, teachers have heavy scientific research task. Students are at loose ends and retreat and escape easily when difficulties appear, which will have bad influences on learning.

According to the above analysis, except for teaching course contents, teachers of freshmen should fully realize freshmen need time to transit from high school to college in learning style, design a complete set of countermeasures 
according to characteristics and contents of the course to let freshmen adapt to learning style in colleges as soon as possible.

\section{B. Psychological Predicaments of Freshmen in the Course of $\mathrm{C}++$ Programming}

At present, the course of $\mathrm{C}++$ Programming is provided in computer major and engineering major. $\mathrm{C}++$ is a widelyused language. As a rudimental language, it brings students' difficulties in learning because of its grand framework, rich contents and flexibility. According to years of teaching experience, students' learning and psychological predicaments are concluded as shown in "Table I".

TABLE I. PSyCHOLOGICAL PREDICAMENT OF FRESHMEN IN THE COURSE OF C++ PROGRAMMING

\begin{tabular}{|l|l|l|}
\hline Phenomenon & \multicolumn{1}{|c|}{ Cause } & \multicolumn{1}{|c|}{$\begin{array}{l}\text { Psychological } \\
\text { predicament }\end{array}$} \\
\hline $\begin{array}{l}\text { Inadaptable } \\
\text { to new } \\
\text { language }\end{array}$ & $\begin{array}{l}\text { Computer language is } \\
\text { different from natural } \\
\text { language } \\
\text { Computer language is } \\
\text { different from } \\
\text { mathematical language. }\end{array}$ & $\begin{array}{l}\text { Sense alienation of } \\
\text { course }\end{array}$ \\
\hline $\begin{array}{l}\text { Big } \\
\text { differences in } \\
\text { learning } \\
\text { effects }\end{array}$ & $\begin{array}{l}\text { High school basis } \\
\text { Extent of using } \\
\text { computer in high } \\
\text { school } \\
\text { Individual difference }\end{array}$ & Self-abasement \\
\hline $\begin{array}{l}\text { Make errors } \\
\text { in } \\
\text { programming }\end{array}$ & $\begin{array}{l}\text { Normal phenomenon in } \\
\text { learning } \\
\text { Unskilled mastery of } \\
\text { classroom knowledge }\end{array}$ & $\begin{array}{l}\text { Depressed and } \\
\text { impatient } \\
\text { Lose heart }\end{array}$ \\
\hline
\end{tabular}

- Different from natural language and mathematical language, advanced computer language has unique characteristics. Students feel inadaptable and have sense of alienation. In the first few weeks of $\mathrm{C}++$ language course, students have to grasp large quantities of concepts and grammatical elements such as character set, vocabulary, expression, operator, data type and input and output. Contents that haven't been learnt involve in programming examples. Students have difficulties in learning this course.

- Students have different understanding of computer and computer programs because of different regions and individuals. Some students come from big cities and more or less contact simple programming language in high school. Most students never contact it. The great differences in students' speed of understanding and learning effects make some students afraid of difficulty and self-abased and seriously influence learning.

- Inevitably, students will make errors in learning this course at first. It is very difficult for students to compile a complete program in the first few weeks because they are unfamiliar with programming tools. It is the only way which must be passed in learning programming, but students will feel depressed when making errors. Without teachers' guidance, students will feel impatient and lose heart in learning this course.

\section{COUNTERMEASURES TO SOLVE PROBLEMS IN LEARNING C++ PROGRAMMING}

According to the above analysis, a complete set of countermeasures is formulated in the course of $\mathrm{C}++$ Programming.

Strategies in teaching idea. Teaching is people oriented and affirms each student is enterprising and admits everyone has multiple intelligence and students have different ability in different aspects. The simple teaching idea is transformed into people oriented education. It makes each student have confidence and enthusiasm in this course through incentive mechanism of educational psychology including external and internal motivation. Some students have learning difficulties and poor enthusiasm in learning. The combination of encouragement in class and after-school tutoring is adopted to help students to pull through and make each student feel the care and respect of teachers.

Before the formal learning of $\mathrm{C}++$ language, the position and role of advanced computer language in computer system, the development history and characteristics of computer language and strengths of $\mathrm{C}++$ language are systematically introduced to make students comprehensively understand the background, characteristics and importance of it and have the sense of sureness.

In teaching contents, when teaching grammar, teachers add living examples related to specialty of students to make them see the role in which computer language play and enhance their learning interests. The whole process of software development is introduced, including question introduction, demand analysis, systematic design, detailed design, and programming, debugging and test, in order to teach students to use $\mathrm{C}++$ language to solve problems and enhance their confidence and learning enthusiasm.

Teachers should integrate theories of educational psychology in classroom teaching and design contents and presentation forms of courseware, way of interactive participation of students, control of the rhythm of teaching and attention to improve classroom effect. In courseware, the five formal lesson-steps should be followed [6]: preparation, presentation, contact and comparison, summary or extract and practical application. Teachers teach each knowledge point and introduce knowledge and its application, make students grasp knowledge and teach them to compile normative and efficient program. Pay attention to the speed of students in reading courseware and explain key words in detail to strengthen the understanding. Besides, teachers realize the great difference of cognitive style of students and give consideration to different types of students in teaching methods. The stimuli-presenting mode of courseware is diversified. Teachers give prominence to the key points and add examples and analogy to strengthen teaching effects. Engineering students have heavy schoolwork, so they are absent-minded and tired in the second half class. It requires teachers to use relaxed and humorous teaching styles and 
attract attentions of students through posing questions to enlighten them to think.

TABLE II. COUNTERMEASURES IN THE COURSE OF C++ PROGRAMMING AND POSITIVE EFFECTS

\begin{tabular}{|c|c|c|c|}
\hline $\begin{array}{c}\text { Counterm } \\
\text { easures }\end{array}$ & Specific practice & Real effect & $\begin{array}{c}\text { Psychological } \\
\text { effect }\end{array}$ \\
\hline $\begin{array}{l}\text { People } \\
\text { oriented } \\
\text { Encourage } \\
\text { students }\end{array}$ & $\begin{array}{l}\text { Admit the } \\
\text { multiple } \\
\text { intelligence of } \\
\text { people } \\
\text { External and } \\
\text { internal } \\
\text { motivation } \\
\text { Encouragement in } \\
\text { class and after- } \\
\text { school tutoring } \\
\end{array}$ & $\begin{array}{l}\text { All students are } \\
\text { not afraid of the } \\
\text { course. } \\
\text { Learning interests } \\
\text { are improved. }\end{array}$ & $\begin{array}{l}\text { Confidence is } \\
\text { enhanced. }\end{array}$ \\
\hline $\begin{array}{l}\text { Improve } \\
\text { teaching } \\
\text { quality }\end{array}$ & $\begin{array}{l}\text { Five formal } \\
\text { lesson-steps } \\
\text { Add examples and } \\
\text { analogy } \\
\text { Relaxed and } \\
\text { humorous } \\
\text { teaching } \\
\text { Raise questions } \\
\text { and interaction }\end{array}$ & $\begin{array}{l}\text { Students } \\
\text { continuously } \\
\text { concentrate on the } \\
\text { class. } \\
\text { Classroom } \\
\text { efficiency } \\
\text { improves. } \\
\text { Students have } \\
\text { profound interests } \\
\text { in classroom. }\end{array}$ & $\begin{array}{l}\text { Students have } \\
\text { more and more } \\
\text { interests in the } \\
\text { course } \\
\text { Begin to think }\end{array}$ \\
\hline $\begin{array}{l}\text { Strengthen } \\
\text { experiment } \\
\text { link }\end{array}$ & $\begin{array}{l}\text { Construct } \\
\text { programming } \\
\text { question bank } \\
\text { Add tasks in after- } \\
\text { school experiment } \\
\text { Provide training } \\
\text { course of } \\
\text { programming } \\
\text { environment } \\
\text { Analyze fallible } \\
\text { points of } \\
\text { programming } \\
\text { Timely guidance } \\
\text { of teachers }\end{array}$ & $\begin{array}{l}\text { Experimental } \\
\text { intensity of } \\
\text { students increases. } \\
\text { Students get } \\
\text { powerful support } \\
\text { in experiment. }\end{array}$ & $\begin{array}{l}\text { Have more and } \\
\text { more } \\
\text { confidence in } \\
\text { programming }\end{array}$ \\
\hline
\end{tabular}

Strengthen experiment link. This course stipulates there are 16 class hours for students to exercise on computer. The time is too little for a language course. Therefore, teachers must assign tasks for students to exercise on computer after school through constructing programming question bank and designing corresponding programming question related to each knowledge point. At the initial stage, students are afraid of difficulties because they are unfamiliar with the language and programming environment. In order to help students to overcome the psychological barrier, teachers should construct teaching resources database in experiment link including training course and videos of programming environment, documents of topic cues in programming question bank and documents to analyze fallible points of students in programming. Meanwhile, teachers open personal contact information (email and WeChat, etc.), so that students can raise questions in the experiment or learning and get timely guidance of teachers. The training video is vivid and has demonstration effects on students. The auxiliary of documents and the guidance of teachers make students get enough support in the experiment link and overcome the depressed psychology, strengthen the experiment effect and systematically support students to enhance their confidence in learning.
The above strategies are concluded in "Table II".

Strategies to solve psychological predicaments and learning difficulties have become mature through years of implementation and continuous improvement. At first, students feel at a loss but they have more confidence in this course, learn and think actively and have profound interests in experiment exercises after four to six weeks of learning. The timely guidance of teachers provides positive psychological support for students. Students and teachers have great affection so students have more interests in this course, adapt to learning styles in colleges within one to two months, which have positive effects on learning of other courses.

\section{CONCLUSION}

The freshmen' psychological predicaments in adaptation to learning style in colleges and their difficulties in learning the course of $\mathrm{C}++$ Programming are analyzed. How these difficulties lead to students' unhealthy psychological experience and then affect the learning of this course is concluded. Countermeasures to solve freshmen's difficulties in learning $\mathrm{C}++$ Programming are proposed, in order to improve students' enthusiasm, confidence and interests in it and let them better adapt to learning style of colleges and study better within a short time.

\section{REFERENCES}

[1] Cheng Guifen, Cao Liying, Yao Yuxia, etc. Teaching Patterns and Methods of C++ Programming. Computer Education, 2010, 21: 135137

[2] Xiao Ming. Application of Case Method of Teaching in C++ Language Programming, Computer Education, 2010, 6: 83-86

[3] Peng Zhaoyi, Zhu Yanhui, Zhou Yu. Research on Practical Teaching in $\mathrm{C}++$ Object Oriented Programming, Computer Education, Computer Education, 2010, 5: 151-154

[4] Han Bing, Guo Yongmei, Hou Huiling. Teaching Practice of Object Oriented Programming $\mathrm{C}++$ of Interest Orientation, Software Engineering, 2016, 19(6): 59-61

[5] Lu Yunhong, Zhou Shiping. Discussion on Teaching Methods of C/C++ Programming, Computer Education, 2014, 22: 90-93

[6] Robert J. Sternberg, Wendy M. Williams et, translated by Zhang Houcan, Educational Psychology, China Light Industry Press, September 2003. 